\title{
Risk level of landslide hazard at Probolinggo district, East Java
}

\author{
Ratna Saraswati, ${ }^{1, *}$ \\ ${ }^{1}$ Geography Department, Faculty Mathematics, and Natural Sciences, Universitas Indonesia, Kampus Baru UI, Depok, 16424, \\ Indonesia
}

\begin{abstract}
Landslide is the third largest disaster in Indonesia, including in Probolinggo. Approximately $50 \%$ of Probolinggo regency area is a potential landslide region. This area is located in the southern part of Probolinggo regency with hilly terrain and slopes. The number of landslide events in 2015-2016 is recorded 21 events. Potential landslide hazard was analyzed by SINMAP (Stability Index Mapping) method using physic condition, slope, digital elevation model, and rainfall. The risk level of landslide hazard is derived from the crosstab between landslide hazard potential and vulnerability index covering exposure aspect, sensitivity, and adaptive capacity with variables consisting of population density, livelihood, the proportion of the vulnerable population, building quality, and the number of poor households. The high risk of landslide hazard in Probolinggo regency is found in four districts of Lumbang, Pakuniran, and Kotaanyar sub-district. Potential landslide areas are spread in the south of Probolinggo Regency, especially in Krucil subdistrict with $15-40 \%$ slopes. Based on the spread of landslide location, as many as $81 \%$ of landslide locations occur in high and medium landslide potential areas.
\end{abstract}

\section{Introduction}

Indonesia is a region that has an undulating morphology from coast to mountain. In line with the situation, then Indonesia is a disaster prone area. Disasters that occur not only natural disasters but also non-natural disasters and social disasters. One of the Natural disasters that hit Indonesia is landslide. According to data from the National Disaster Management Agency (BNPB) in 2016, there is 3649 number of landslide events from 1998 to 2016, spread across Indonesia [1]. East Java Province is one of the high potential areas of landslide disaster. This is due to hilly and mountainous of its topography. Besides, it is also caused by the high density of population in the hilly area that causing pressure on the ecosystem. [2]. The landslides are certainly very detrimental to the community because of the resulting loss of life and the destruction of facilities and infrastructure such as road cuts, damage to irrigation channels, settlements, markets and so forth.

Landslide is a general term for a wide blend of downslope advancements of earth materials that result in the distinguishable dropping and outward advancement of soil, rock, and vegetation influenced by gravity. The materials may move by falling, toppling, sliding, spreading, or gushing. A couple of landslides are fast, happening in seconds, while others may take hours, weeks or more [3].

Probolinggo regency is one of the districts in Indonesia that affected by the disaster. Throughout the year 2016, according to the Regional Disaster Management Agency (BPBD) in Probolinggo District recorded 72 incidents of disaster including landslides, drought, tidal flood, forest fires and others. Landslides dominate throughout 2016 as much as 29 percent, wind 25 percent, flood 17 percent, fire, drought, and eruption as much as 13 percent. While the affected area as much as 66 percent of the 24 districts in Probolinggo District [4].

From the above backgrounds then the research problem to be studied in this paper is: what is the risk level of landslide disaster in Probolinggo regency.

\section{Methodology}

Identification of potential areas of landslide disaster can be achieved in various ways, such as SINMAP (Stability Index Mapping), Fuzzy Logic, the method of logistic regression, etc [5]. Based on Acharya research, SINMAP model has the best result for identification potential landslide. [6]. This method is used to determine a region with potential or no potential landslide based on geographic information. SINMAP excellence can provide an overview of the potential landslides of a region by combining hydrological elements such as rainfall, soil conditions, and slopes [7]. Then followed by mapping of potential landslide areas, combined with landslide events that occurred in Probolinggo District. This mapping has also been widely used in several countries, such as in Ratnapura City, Sri Lanka by

*Corresponding author: ratna.saraswati@ui.ac.id 
Weerasinghe [8], which in its research found as much as $72 \%$ of Ratnapura City area of $153 \mathrm{~km}^{2}$ categorized to areas with potential landslides.

After obtaining landslide potential data, then analyze data of vulnerability of area based on the social factor, that is from exposure, sensitivity and adaptive capacity against shocks in landslide disasters. The exposure determinant indicator is limited to population density and livelihoods; the sensitivity determinant indicator is limited to the proportion of vulnerable (elderly-old) and quality of the building; as well as adaptive capacity is limited to the number of homes the stairs are poor. The vulnerability criteria used in this study are described in Table 1. While the formulas used are: function $\mathrm{V}=\mathrm{f}(\mathrm{E}$, $\mathrm{S}, \mathrm{A})$, where $\mathrm{E}$ is the exposure, $\mathrm{S}$ is sensitivity and $\mathrm{A}$ is adaptive capacity [9]. The degree of vulnerability is also affected by conditions of community sensitivity and their ability to adapt it [10].

Regional vulnerability data and landslide potential data are created by crosstab to obtain disaster risk level. The level of disaster risk is divided into three classifications: low risk, medium risk, and high risk.

Table 1. Vulnerability criteria

\begin{tabular}{|c|c|c|c|c|}
\hline Variable & Assumption & & Vulnerability & \\
\hline & & Low & Moderate & High \\
\hline $\begin{array}{l}\text { Population } \\
\text { Density }\end{array}$ & $\begin{array}{l}\text { The higher } \\
\text { the population } \\
\text { density, the } \\
\text { higher the } \\
\text { vulnerability }\end{array}$ & $\begin{array}{l}<700 \\
\text { person } \\
/ \mathrm{km} 2\end{array}$ & $\begin{array}{l}700-1300 \\
\text { person/km2 }\end{array}$ & $\begin{array}{l}>1300 \\
\text { person/ } \\
\text { km2 }\end{array}$ \\
\hline $\begin{array}{l}\text { Occupatio } \\
\mathrm{n}\end{array}$ & $\begin{array}{l}\text { The } \\
\text { population } \\
\text { working in } \\
\text { the formal } \\
\text { sector will } \\
\text { have a lower } \\
\text { level of } \\
\text { exposure } \\
\text { compared to } \\
\text { those working } \\
\text { in the } \\
\text { informal } \\
\text { sector }\end{array}$ & $\begin{array}{l}\text { Forma } \\
1\end{array}$ & Formal & $\begin{array}{l}\text { Infor } \\
\text { mal }\end{array}$ \\
\hline $\begin{array}{l}\text { Population } \\
\text { Proportion } \\
\text { Infant- } \\
\text { Senior } \\
\text { Age }\end{array}$ & $\begin{array}{l}\text { The higher } \\
\text { the proportion } \\
\text { of infant- } \\
\text { senior age } \\
\text { then the } \\
\text { higher the } \\
\text { sensitivity } \\
\text { will be }\end{array}$ & $\begin{array}{l}0.11- \\
0.13\end{array}$ & $0.14-0.16$ & $\begin{array}{l}0.17- \\
0.19\end{array}$ \\
\hline $\begin{array}{l}\text { Building } \\
\text { Quality }\end{array}$ & $\begin{array}{l}\text { Temporary } \\
\text { settlement } \\
\text { type will have } \\
\text { higher } \\
\text { sensitivity }\end{array}$ & $\begin{array}{l}\text { Perma } \\
\text { nent }\end{array}$ & $\begin{array}{l}\text { Semi- } \\
\text { Permanent }\end{array}$ & $\begin{array}{l}\text { Tempo } \\
\text { rary }\end{array}$ \\
\hline $\begin{array}{l}\text { Poor } \\
\text { Household } \\
\text { Number }\end{array}$ & $\begin{array}{l}\text { The higher } \\
\text { the number } \\
\text { poor } \\
\text { household the } \\
\text { lower their } \\
\text { ability to } \\
\text { handle } \\
\text { disaster }\end{array}$ & $<20 \%$ & $20 \%-50 \%$ & $>50 \%$ \\
\hline
\end{tabular}

Table 2. Landslide hazard risk level

\begin{tabular}{|l|c|l|l|l|}
\hline Vulnerability & High & & & \\
\cline { 2 - 5 } & Moderate & & & \\
\cline { 2 - 5 } & Low & & & \\
\hline \multirow{2}{*}{} & Low & Moderate & High \\
\cline { 3 - 5 } & \multicolumn{3}{|c|}{ Hazard } \\
\hline
\end{tabular}

\section{Results}

\subsection{Area of potential landslide hazard}

Potential landslide hazard areas in Probolinggo district are derived from Nanda's research in 2017 [12]. The result of processing SINMAP model, Probolinggo regency has four areas of the potential danger of landslides that is not potential, low potential, medium potential, and high potential. Based on the total area, the potential landslide hazard area in Probolinggo regency is $49.70 \%$. This is an area that does not have landslide potential, so another $50.30 \%$ is an area with landslide potential (see Table 3 and Map 1).

Table 3. Landslide hazard potential area Probolinggo district (Ha)

\begin{tabular}{|c|c|c|}
\hline $\begin{array}{c}\text { Landslide Hazard } \\
\text { Potential }\end{array}$ & Width (ha) & Percentage \\
\hline Non-Potential & 84.302 & 49,70 \\
\hline Low Potential & 17.663 & 10,41 \\
\hline Moderate Potential & 36.105 & 21,29 \\
\hline High Potential & 31.541 & 19,60 \\
\hline Total & 169.610 & 100 \\
\hline
\end{tabular}

Source : [12]

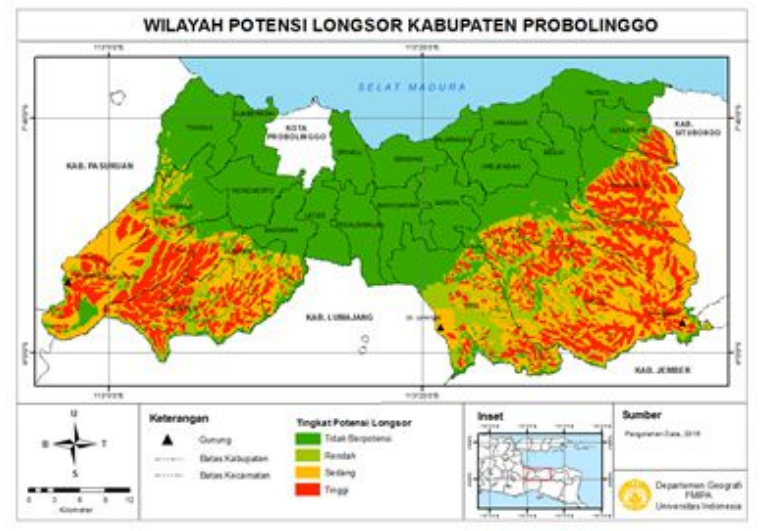

Fig. 1. Landslide hazard potential of Probolinggo district [12]

Low level of potential landslide areas in Probolinggo District are spread over the northern part of the Regency, especially in coastal areas bordering the Madura Strait. 
Conversely, the area that has a landslide potential in Probolinggo regency is widely spread in the southern part of the district. Potential landslide area in Probolinggo regency is dominated by moderate landslide hazard areas with an area of $36.105 \mathrm{Ha}$ or equal to $21.29 \%$ of the total area of Probolinggo Regency. Subsequently, the high landslide hazard potential area with a total area of 31,541 ha or $19.60 \%$, and the area of low landslide hazard potential has the smallest area of 17,663 ha or $10.41 \%$ of the total area of Probolinggo Regency. If assessed by its sub-district, the landslide potential areas are spread over several districts in Probolinggo District. Based on the results of processing using SINMAP model, there are 13 districts that have a low potential area, 12 subdistricts with the medium potential area and 10 districts that have high potential area. Distribution of landslide potential area by subdistrict in Probolinggo regency is shown in following Table 4.

Table 4. The potential landslide area by subdistrict (Ha)

\begin{tabular}{|c|c|c|c|}
\hline \multirow{2}{*}{ Subdistrict } & \multicolumn{3}{|c|}{ Potential Landslide Area } \\
\hline & $\begin{array}{l}\text { Low } \\
\text { Potential }\end{array}$ & $\begin{array}{l}\text { Moderate } \\
\text { Potential }\end{array}$ & High Potential \\
\hline Tiris & $4.453,54$ & $4.319,75$ & $1.932,71$ \\
\hline Krucil & $3.962,01$ & $10.472,65$ & $8.571,67$ \\
\hline Sumber & $2.057,11$ & $3.439,28$ & $4.555,28$ \\
\hline Sukapura & $1.660,00$ & $4.268,37$ & $4.886,51$ \\
\hline Kuripan & $1.458,36$ & $2.485,84$ & $1.907,78$ \\
\hline Gading & $1.381,81$ & $4.455,64$ & $3.725,20$ \\
\hline Lumbang & $1.202,27$ & $2.557,67$ & 952,22 \\
\hline Pakuniran & 817,27 & $3.236,31$ & $4.282,86$ \\
\hline Kotaanyar & 382,97 & 396,28 & 600,61 \\
\hline Bantaran & 210,92 & 329,56 & 125,70 \\
\hline Tongas & 66,34 & 140,88 & 0,00 \\
\hline Maron & 5,43 & 0,00 & 0,00 \\
\hline Besuk & 4,96 & 3,05 & 0,00 \\
\hline Total & $17.662,96$ & $36.105,28$ & $31.540,55$ \\
\hline
\end{tabular}

\subsection{Landslide incident location}

The location of the landslide in Probolinggo Regency, mostly in Subdistrict Tiris (low and medium potential), whereas in Sukapura District which is included in the high potential there are 7 incidents, as presented in Table 5.
Table 5. Landslide incident number per sub district

\begin{tabular}{|c|c|c|c|}
\hline $\begin{array}{c}\text { Landslide } \\
\text { Potential Level }\end{array}$ & Subdistrict & $\begin{array}{c}\text { Landslide } \\
\text { Incident } \\
\text { Number }\end{array}$ & Total \\
\hline Non-Potential & Dringu & 1 & 1 \\
\hline Low Potential & Tiris & 3 & 3 \\
\hline $\begin{array}{c}\text { Moderate } \\
\text { Potential }\end{array}$ & Tiris & 6 & 6 \\
\hline \multirow{2}{*}{\begin{tabular}{c} 
High Potential \\
\cline { 1 - 3 }
\end{tabular}} & Pading & 1 & \multirow{2}{*}{11} \\
\cline { 2 - 3 } & Sukapura & 7 & \multirow{2}{*}{21} \\
\cline { 2 - 3 } & Sumber & 1 & \\
\hline \multicolumn{3}{|c|}{ Total } & \\
\hline
\end{tabular}

Source: [12]

\subsection{The social vulnerability of landslide hazard}

The vulnerability of landslide hazard in this paper is based on social factors in Probolinggo District as shown in Table 1, from the level of exposure with variable population density and livelihood. Population density in Probolinggo district are as follow. Two districts with high population density while the livelihood of the population is dominated by non-formal livelihoods. The level of sensitivity is measured from the age and the quality of the building. In Probolinggo Regency the proportion of toddler-old age is the highest in the medium classification of $0.14-0.16$. While for the quality of the building, 19 sub-districts of 24 districts are dominated by the quality of permanent houses. Adaptive capacity, analyzed by poor households, it revealed that only 5 districts have a value above $50 \%$ (See figure 2 ).

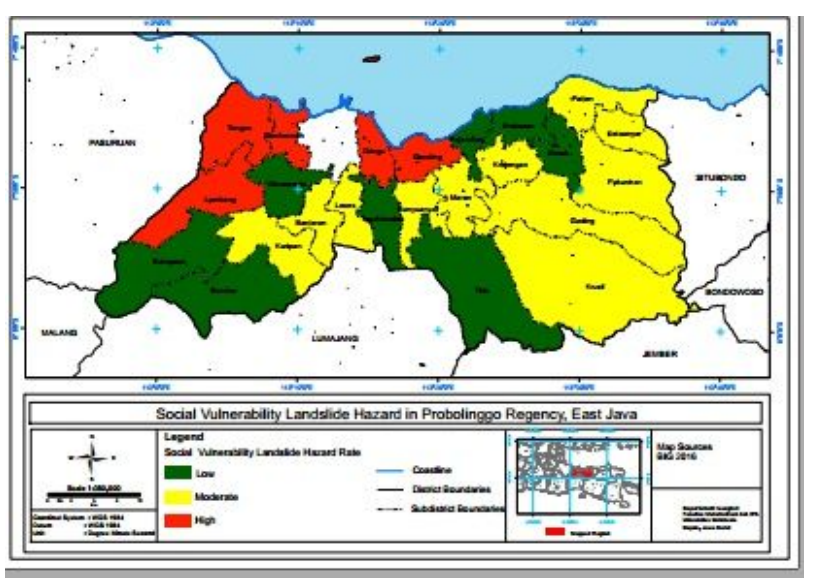

Fig. 2. Social vulnerability landslide hazard

\subsection{Level of risk of landslide hazards}

Risk level of landslide hazard in Probolinggo Regency, which havs high risk are found in District Pakuniran, Lumbang, and Kotaanyar. Those sub-districts are at varying heights as well as its slopes and hilly terrain (See 
Table 6). In addition to the sub-districts in Table 6, the potential for a high social vulnerability are found in Sumberasih, Gending and Dringu districts.

Table 6. Landside hazard risk level

\begin{tabular}{|c|c|c|c|}
\hline $\begin{array}{c}\text { Subdistric } \\
\mathbf{t}\end{array}$ & $\begin{array}{c}\text { Landslide } \\
\text { Hazard }\end{array}$ & Vulnerability & Risk \\
\hline Tiris & L & L & L \\
\hline Krucil & M & M & M \\
\hline Sumber & H & L & M \\
\hline Sukapura & H & L & M \\
\hline Kuripan & M & M & M \\
\hline Gading & M & M & M \\
\hline Lumbang & M & H & H \\
\hline Pakuniran & H & M & H \\
\hline Kotaanyar & H & M & H \\
\hline Bantaran & M & M & M \\
\hline Tongas & M & H & M \\
\hline Maron & L & M & L \\
\hline Besuk & L & L & L \\
\hline
\end{tabular}

$\mathrm{L}=$ low, $\mathrm{M}=$ moderate, $\mathrm{H}=$ high

Observation on Table 7 shows landslide events that occurred in Probolinggo District in 2015-2016, SubDistrict Dringu has a high vulnerability to landslide hazard, the number of incidents 1 , while Sukapura District with the most incidents, has vulnerability with medium potential.

Table 7. Risk level

\begin{tabular}{|c|c|c|c|}
\hline $\begin{array}{c}\text { Landslide } \\
\text { Potential } \\
\text { Level }\end{array}$ & Subdistrict & $\begin{array}{c}\text { Incident } \\
\text { Total }\end{array}$ & Vulnerability \\
\hline Non-Potential & Dringu & 1 & $\begin{array}{c}\text { High } \\
\text { Potential } \\
\end{array}$ \\
\hline Low Potential & Tiris & 3 & Low Potential \\
\hline $\begin{array}{l}\text { Moderate } \\
\text { Potential } \\
\end{array}$ & Tiris & 6 & Low Potential \\
\hline \multirow{4}{*}{$\begin{array}{c}\text { High } \\
\text { Potential }\end{array}$} & Gading & 1 & $\begin{array}{l}\text { Medium } \\
\text { Potential }\end{array}$ \\
\hline & Pakuniran & 2 & $\begin{array}{l}\text { Medium } \\
\text { Potential } \\
\end{array}$ \\
\hline & Sukapura & 7 & Low Potential \\
\hline & Sumber & 1 & Low Potential \\
\hline
\end{tabular}

\section{Conclusion}

Potential landslide areas are spread in the south of Probolinggo Regency, especially in Krucil Sub district with $15-40 \%$ slopes. Based on the spread of landslide location, as many as $81 \%$ of landslide locations occur in high and medium landslide potential areas. The high-risk level of landslide hazard in Probolinggo regency are found in three districts of Lumbang, Pakuniran and Kotaanyar sub-districts. Meanwhile, the moderate risk of landslide hazard occurs in Krucil, Sumber, Sukapura, Kuripan, Gading, Bantaran and Tongas sub-district.

\section{References}

1. National Board For Disaster Management

2. Effendi, A.Y \& T. Hariyanto (2016). Making Map of Landslide Prone Areas By Using Fuzzy Logic Method.. (Case Study Probolinggo District). Technic Journal ITS Vol. 5. No.2. ISSN 2337-3539

3. Bhattacharjee. Landslide Mitigation Various Techniques. International Journal of Applied Engineering Research. ISSN 0973-4562 Volume 11,Number 8. 2016

4. Regional Disaster Management Agency of Probolinggo District. Disaster Events throughout the year 2016. http://bpbd.probolinggokab.go.id/id/berita/kejad ian-bencana-sepanjang-tahun-2016/. 2017

5. Lin, L., Q, Lin., Y. Wang (2017). Landslide susceptibility mapping on a global scale using the method of logistic regression. Natural Hazards Earth System Sciences, 17,1441-1424. Https://doi.org/10.5194/nhess-17-1411-2017

6. Acharya,G.(2003). GIS Approach for slope Stability Risk Analysis. A Case Study from Nepal. Thesis. Vrije Universiteit Brussel Belgium. Universiteit Gent.

7. Pack, R., Tarboton, D., Goodwin, C., \& Prasad, A. (2005). A Stability Index Approach To Terrain Stability Hazard Mapping: Sinmap User's Manual. Utah State University .

8. Weerasinghe, K.M. (2006). Use of a Deterministic Slope Stability Predicting Tool

9. Turner, B. L., II, Kasperson, R. E., Matson P. A., Mc Carthy, J. J., Corell, R. W.,Christensen, L., Eckley, N., Kasperson, J. X., Luesr, A., Martello, M. 1.,Polsky, C., Pulsipher, A. dan Schiller, A. (2003). A Framework for Vulnerability Analysis In Sustainability Science, Proc. Natl. Acad. Sci.U.S.A, Vol. 100: 80748079

10. Metzger, M.J., Rounsevell, M.D.A., Acosta, L., Leemans, L. dan Schoter, L.,(2006). The Vulnerability of Ecosystem Services to Land Use Change. Journal Agriculture, Ecosystem and Enviroment, p. 69-85

11. Muta'ali, L. (2012). Environmental Carrying Capacity For Regional Development Planning. Faculty Geography Publisher (BPFG) University of Gajah Mada, Yogyakarta

12. Nanda, R, F., R.Saraswati (2018). Place Exposure Pattern Towards Landslide Disaster Due to Heavy Rainfall in Probolinggo District, East Java Province. Geography and Sustainable Divelopment Proceeding 2018. ISBN: 978-97916609-5-2. 